INTERNATIONAL JOURNAL OF RESEARCHES IN BIOSCIENCES, AGRICULTURE AND TECHNOLOGY

(C) VISHWASHANTI MULTIPURPOSE SOCIETY (Global Peace Multipurpose Society) R. No. MH-659/13(N) www.vmsindia.org

\title{
IMPACT OF SHIFTING CULTIVATION IN THE KOYNA CATCHMENT AREA (MAHARASHTRA INDIA)
}

\author{
K. P. Shinde ${ }^{1}$, R. V. Shejwal ${ }^{2}$ and T. C. Gaupale ${ }^{1}$ \\ ${ }^{1}$ Department of Zoology, Vivekanand College Kolhapur, Maharashtra, 416003, India \\ 2Department of Zoology, Lal Bahadur Shasti College Satara, Maharashtra, India \\ kiran.shinde@gmail.com
}

\begin{abstract}
:
Agriculture is the main occupation of Kunbi, Maratha and Dhangar communities of western ghat with animal husbandry as a secondary occupation. The traditional practices carried out at this region by two ways including cultivation in river valley and terrace and shifting cultivation about more than ten acres area under agriculture practices. Distribution of land holding about $13.9 \%$ with their own, other land of government or on lease. The traditional slash burn type practices at slopes of western ghat, set on fire during premonsoon carried out. These traditional agricultural practices of shifting cultivation and Rab have prove to be disastrous for animal diversity in study area. This reduces the habitat, fragments, of vegetation, destroy plant seeds, microflora, fauna, and bring about hindrance in regeneration of vegetation. Top soil erosion, landslides, loss of water table are the side effects. Keywords: Koyna catchment, shifting cultivation, Rab, Diversity
\end{abstract}

\section{Introduction:}

Agriculture is the main backbone of the Indians. In the agriculture revolution the water management is the main aim for agriculture development. India is the most important dam building nation in the world, 1500 dams have been built in the country at a cost of rs 10,556 crores. These multipurpose reservoirs were built to meet the irrigation requirements of the country. In case of resettlements of the country of displaced persons, the planners grant compensation in the form of land elsewhere, they fail to realize the emotional and cultural attachment that people have to their ancestral homes. The displaced population generally does not benefit from the fruits of development. The maintenance of a proper cover of vegetation in the catchment areas of any reservoir is vital to its proper functioning. Such vegetation regulates flow of water in the reservoir, preventing floods and maintaining water flow in the dry season and more crucially prevents excessive erosion of soil. Soil erosion in the catchment area and the consequent siltation of reservoirs has been a major problem in India. The consequent of drastic reduction in the useful life of the reservoirs has obliviously serious economic implications (Gadgil 1981)

Koyna wildlife Sanctury (423.5Sq Km) is one such area was declared in September 1985 by the government of maharashtra. Also the area in the country having specific biological diversity and have been identified as areas of importance for Biosphere reserves (Gadgi and Meher Hamjo, 1968). During the investigations all the settlements $(n=1)$ from the study area were surved for Kunbi, Maratha, and Dhangar communities. The study was carried out from June 1986 till August 1987. In which a detail survey was conducted in 479 households in all the villages in the study area from the Koyana wildlife Sanctuary catchment area.

\section{Materials and Methods:}

Study area: the Koynavalley is in the Satara district at the Western limit of Decan table land. It lies between 16045' and 18 $10^{\prime}$ north and 73045' and 73०15' cast. The valley is distributed in Jawali, Mahabaleshwar, and Patan tahasil, in Satara district Maharashtra. The study was conducted for a period of 14 months from 1986 till August 1987. After the initial review of literature and government report, field visit were made to determine the study area.

\section{Observation:}

Agriculture is the main occupation of the people in the study area. The local population basically Kunbi, Maratha and Dhanagar community is involved in traditional agriculture. Dhangar community is traditionally pastrol momadic community of the Western ghat, which has switched over to agricultureas the main occupation and animal husbandry as second occupation in the recent past, conventionally the agriculture practices in the area of two type.

1. Cultivation in the river valley and terrace where paddy is grown on the perennial water supply or rained cultivation.

2. Shifting cultivation where hill millets are grown on hill slopes with the help of monsoon rains.

The distribution of land holding in the area is large. A significant percent is 13.9 of the households did not have any land holding of their own. They mainly cultivated other land on 
lease or government land. About $20 \%$ of the households had only 1-2 acres of land. The traditional cultivation lands in the valley and on the lower terrace are absent in case of $9.6 \%$ households. About $50 \%$ of the people had hardly 1-2 acres of this land and only $12-13 \%$ of the households had more than 10 acres of cultivated land. The people from the east catchment i.e. village kusawade, Gojegaon, Aral and Kathi.

The shifting cultivation was comparatively a common practice in the region $51.7 \%$ of the households did not have land where they performed this practice. About $37 \%$ of the people had only 1-2 acrersof land brought under shifting cultivation every year. About 10 $\%$ of the respondent had 3-9 acres under shifting cultivation and only $1.8 \%$ had more than 10 acres of land under shifting cultivation during the period of investigation i.e. village zadoli, Zadol-Ambeghar and Dicholi in the west catchment.

Shifting cultivation, locally as kumbhari, is a traditional slash and burn type of agriculture practice is very common on the slopes of the western ghat. The exposed land is need for the cultivation of poor quality hill millets namely Nachara and Vari. The poor quality soil does not support any crop after two to three years and it is left fallow for another 4-5 years till the secondary vegetation covers the soil. The shifting cultivation is performed in rotational manners after 4-5 years on the same land. However, now this practice has became a serious threat to the environment of the area in general and its biological diversity in particular. The fire causes permanent damage to the flora and also the animal diversity which in turn drastically reduces the survival chances of the animal population in the fragmented forests. The traditional crops grows in the study area are paddy in the low lying areas and flat lands and Nachara, vari, Rai, till on the

Steep hill slopes. But after the dam construction with the help of new roads and better communication facility about seven croops are grown in the study area i.e. wheat, maize. Jawari, gram, ground nut, sugarcane, and vegetables.

Conclusion: In the present study area the traditional agriculture practices of shifting cultivation and Rab have oproved to be disastrous for animal diversity. It reduces the habitat, fragments of vegetation, destroy the plant seeds, micro fauna and flora of the region and brings hindrance in regeneration of vegetation, top soil erosion, landslides loss of water table are the side effects of these damage. Because of sensitive nature of the area as a vital catchment of the Koyna Dam which supplies major share of electricity to the most industrialized state in the country and lift irrigation for agriculture? So it must be protected with totally human population rehabilitated to outside the catchment and it keep vegetation for nature or the entire Koyna catchment into Biosphere reserve on scientific basis.

\section{Acknowledgement}

The authors are thankful to Western Ghats research project New Delhi and Department of Zoology Shivaji University, Kolhapur.

\section{References:}

Gadgil Madhav and Kailash C. Malhotra (1979) Ecology of a pasteral cast: The gavali ,Dhangar of penin sular India. Pp 1-109.

Gadgil Madhav (1979): Hill dam and forest : Some field from western ghats in proceeding of Indian academy of sciences. Pp291-303.

Gadgil Madhav (1981): Dams, hills and forest in major dams a second looly. Pp 12-20.

Gadgil Madhav and Hanji M. (1986): Localities of great significance to conservation of Indias biological divercity, in proceeding Indian academy of sciences. Pp 165-180.

Samant jay and Seren A. (1988): Interlum experts of the project, studies on the potential and conservation of resources of animal origin from western ghat.

Shinde Kiran (1989): impact of dam construction and agriculture practices in the Koyna catchment. M. Phil dissertation in zoology. PP 1-59.

Samant Jay (1987): Human impact on the conservation of biological diversity in the wild life sanctuaries in western ghats. XI symposium of intertropical ecology at Varanasi.Pp 1-15. 